\title{
PROTOCOL TO AMEND THE AGREEMENT ON THE COMMON EFFECTIVE PREFERENTIAL TARIFF (CEPT) SCHEME FOR THE ASEAN FREE TRADE AREA (AFTA) ${ }^{2}$ \\ Bangkok, 15 December 1995
}

The Governments of . . ., Member States of the Association of South East Asian Nations (ASEAN);

Noting the Agreement on the Common Effective Preferential Tariff (CEPT) Scheme for the ASEAN Free Trade Area (AFTA) ('the Agreement') signed in Singapore on 28 January 1992 ;

...

Recognising the need to amend the Agreement to reflect the latest developments in ASEAN;

Have agreed as follows:

\section{Article 1}

Article 2, paragraphs 3, 5 and 6 of the Agreement be amended to read as follows:

“3. Exclusions at the HS 8/9 digit level for specific products are permitted for those Member States, which are temporarily not ready to include such products in the CEPT Scheme. For specific products, which are sensitive to a Member State, pursuant to Article 1(3) of the Framework Agreement on Enhancing ASEAN Economic Cooperation, a Member State may exclude products from the CEPT Scheme, subject to a waiver of any concession herein provided for such products. These temporarily excluded products are to be gradually included into the CEPT by 1 January 2000 .

5. All manufactured products, including capital goods, and agricultural products shall be in the CEPT Scheme. These products shall automatically be subject to the schedule of tariff reduction set out in Article 4 of the Agreement as revised in Article 3 of this Protocol. In respect of PTA items, the schedule of tariff reduction provided for in the revised Article 4(A) set out in Article 3 of this Protocol shall be applied, taking into account the tariff rate after the application of the existing margin of preference (MOP)as at 31 December 1992.

6. All products under the PTA which are not in the list for tariff reductions of the CEPT Scheme shall continue to enjoy the MOPs existing as at 31 December 1992."

\section{Article 2}

Article 3 of the Agreement be amended to read as follows:

"This Agreement shall apply to all manufactured products including capital goods, and agricultural products."

\footnotetext{
${ }^{2}$ Text from op.cit.n.1 p.88. For the Agreement, see Vol. 2, p. 415.
} 


\section{Article 3}

Article 4 of the Agreement be substituted with the following:

"Schedule of Tariff Reduction and Enjoyment of Concessions

A. Schedule of Tariff Reduction

1. Member States agree to the following schedule of effective preferential tariff reductions:

a. The reduction from existing tariff rates to $20 \%$ shall be completed within a time frame of 5 years, from 1 January 1993, subject to a programme of reduction to be decided by each Member State, which shall be announced at the start of the programme. Member States are encouraged to adopt an annual rate of reduction, which shall be $(\mathrm{X}-20) \% / 5$, where $\mathrm{X}$ equals the existing tariff rates of individual Member States.

b. The subsequent reduction of tariff rates from $20 \%$ or below shall be completed within a time frame of 5 years. The rate of reduction shall be at a minimum of $5 \%$ quantum per reduction. A programme of reduction to be decided by each Member State shall be announced at the start of the programme.

c. For products with existing tariff rates of $20 \%$ or below as at 1 January 1993, Member States shall decide upon a programme of tariff reductions, and announce at the start, the schedule of tariff reductions.

2. The above schedule of tariff reduction shall not prevent Member States from immediately reducing their tariffs to $0 \%-5 \%$ or following an accelerated schedule of tariff reduction.

\section{B. Enjoyment of Concessions}

Subject to Articles 4(A)(1b) and 4(A)(1c) of the Agreement, products which reach, or are at tariff rates of $20 \%$ or below, shall automatically enjoy the concessions."

\section{Article 4}

The following be inserted after Article 9 as a new Article 9A to the Agreement:

\section{"Accession of New Members}

New Members of ASEAN shall accede to this Agreement on terms and conditions, which are consistent with the Framework Agreement on Enhancing ASEAN Economic Cooperation (1992) and the Agreement, and which have been agreed between them and the existing Members of ASEAN."

\section{Article 5}

This Protocol shall enter into force upon the deposit of instruments of ratification or acceptance by all signatory governments with the Secretary-General of ASEAN which shall be done not later than 1 January 1996.

This Protocol shall be deposited with the Secretary-General of ASEAN, who shall promptly furnish a certified copy thereof to each Member Country. 